Original Article

\title{
PHYTOCHEMICAL STUDY AND THE ANTIPROLIFERATIVE ACTIVITY OF INULA VULGARIS SPECIES GROWN IN LEBANON
}

\author{
ASSI M. ${ }^{*}$, USTA J. ${ }^{2}$, MOUNIMNE Y. ${ }^{3}$, ABOUL-ELA M. ${ }^{1}$, EL LAKANY A. ${ }^{1}$ \\ 1Department of Pharmaceutical Sciences, Faculty of Pharmacy, Beirut Arab University, Beirut, Lebanon, ${ }^{2}$ Department of Biochemistry and \\ Molecular Genetics, Faculty of Medicine, American University of Beirut, Beirut, Lebanon, ${ }^{3} \mathrm{~K}, \mathrm{~A}, \mathrm{~S}$, Central Research Science Laboratory, \\ American University of Beirut, Bless Street, Beirut, Lebanon \\ Email: honorletter@hotmail.com
}

Received: 27 Feb 2016 Revised and Accepted: 19 Jun 2017

\begin{abstract}
Objective: Cancer represents the second leading cause of death after stroke and heart diseases. Plant extracts have long been used in traditional medicine for the prevention and treatment of many illnesses, including some types of cancer. The aim of this study was to evaluate the antiproliferative effects of ethyl acetate fractions of two Lebanese herbs: Inula viscosa (I. vis) and Inula vulgaris (I. vul).

Methods: Plants were extracted with ethanol followed by ethyl acetate, then dried and tested on three cell lines including $\mathrm{CaCO}_{2}, \mathrm{HepG}_{2}$, and $\mathrm{MCF}_{7}$, to check for their viability and antiproliferative activity, using trypan blue exclusion and 3-(4,5-dimethylthiazol-2-yl)-2,5-diphenyltetrazolium bromide (MTT) assays. Proton $\left({ }^{1} \mathrm{H}\right)$ and carbon $\left({ }^{13} \mathrm{C}\right)$ nuclear magnetic resonance spectrometry (NMR) were used to identify the compounds that have been isolated from both Inula species.

Results: The current findings were consistent for both trypan blue and MTT assays. The results showed that the most potent effect for $I$. vul was HepG2 (IC $5020 \mu \mathrm{g} / \mathrm{ml}, 27 \mu \mathrm{g} / \mathrm{ml})$, and for I. vis on MCF7 $(9 \mu \mathrm{g} / \mathrm{ml}, 15 \mu \mathrm{g} / \mathrm{ml})$ and $\mathrm{CaCO}_{2}(12 \mu \mathrm{g} / \mathrm{ml}, 22 \mu \mathrm{g} / \mathrm{ml})$ in the two mentioned assays respectively. However, insignificant differences were observed among the studied plants for each of the evaluated cells indicating comparable potencies. Quercetin, quercetin glycoside, and epicatechin derivatives were isolated by fractionation on column chromatography and identified using NMR spectroscopy.
\end{abstract}

Conclusion: The antiproliferative activities of the two plants could be related to their content that is significant for high levels of secondary metabolites. The identification of those compounds is necessary to establish a relationship between their chemical structures and their activities.

Keywords: Inula vulgaris, Inula viscosa, Antiproliferative; MTT assay, Trypan blue

(C) 2017 The Authors. Published by Innovare Academic Sciences Pvt Ltd. This is an open access article under the CC BY license (http://creativecommons.org/licenses/by/4.0/) DOI: http://dx.doi.org/10.22159/ijpps.2017v9i8.18181

\section{INTRODUCTION}

The genus Inula (I.) comprises more than one hundred species widespread in temperate regions of Europe and Asia [1]. In Lebanon, 7 species have been identified and are widely spread. Those include I. helenium, I. graveolens, I. crithmoides, I. salicina, I. viscosa (I. vis) and I. vulgaris (I. vul). In addition to those, there is I. heterolepis species, which has vanished and has been reported to be extinct [2].

Previous studies have reported the wide use of $I$. vis in the treatment of various conditions due to its anti-inflammatory [3], anticancer [4], antimicrobial [5], anti-stressor [6], antioxidant [7], anti-hepatotoxic, cardioprotective [8], and anesthetic effects [9]. It is noteworthy that I. vul is locally grown in Lebanon in many areas but has not been studied before.

The characteristic compounds of the genus, including sesquiterpene lactones, flavonoids and other phenolic compounds, are involved in a network of biological effects; in consequence, the majority of the experimental studies are focused on the effects of these secondary metabolites [1]

This study aims at investigating the in vitro antiproliferative effects of the Lebanese $I$. vul against three cancer cell lines, in comparison to the Lebanese I. vis. The antiproliferative activity will be correlated to some isolated compounds, in particular, flavonoids and phenolic compounds.

Cancer is one of the leading causes of death worldwide which has been attributed to many factors that have influenced the increase in the number of cases. Some of the direct factors include the growth of the population, ageing, adoption of life style behaviours that are known to cause cancer [10]. The incidence rates of cancer are expected to approach 296.0 and 339.5 cases per 100,000 for males and females, respectively [11]. Lung and colon cancers are among the most common expected types [11]. Plants have had a long history of use in the treatment of cancer [12], and are still considered as effective sources of biologically active compounds [13]. Many prescribed products in the world have originated from natural plants and their derivatives [13]. I. vul has not been previously studied or tested for its phytochemical or pharmacological applications; this is the first analysis on this grown species worldwide.

\section{MATERIALS AND METHODS}

\section{Chemicals}

Petroleum ether (PE) 40-60 ${ }^{\circ} \mathrm{C}$, dichloromethane (DCM), ethyl acetate (EtAc) and methanol $(\mathrm{MeOH})$ solvents were used for extraction and fractionation. All solvents were purchased from Sigma-Aldrich Company with a high degree of purity (HPLC grade except PE). Silica gel 60 (60-100 mesh) was used in column chromatography and was purchased from the same company too. Anisaldehyde solution was used as a spraying reagent for TLC plates. It was prepared according to the specifications of USP, by dissolving $0.5 \mathrm{ml}$ anisaldehyde in glacial acetic acid/conc. $\mathrm{H}_{2} \mathrm{SO}_{4}$ (50 ml: $1 \mathrm{ml}$ ), then the solution was transferred into a spraying bottle [14].

\section{Cell culture reagents}

Dulbecco's modified Eagle's medium (DMEM), 10\% fetal bovine serum (FBS), L-glutamine containing 100 units/ml of penicillin G sodium and 100 units/ml of streptomycin sulfate, were all purchased from SigmaAldrich Company. Cell proliferation kits containing MTT (3-(4,5dimethylthiazol-2-yl)-2,5-diphenyltetrazolium bromide) and the solubilizing agent were bought from Roche Life Science Company.

\section{Equipment}

Extracts were concentrated by a Rotavapor-R30 at $40^{\circ} \mathrm{C}$. 
Preliminary thin layer chromatography (TLC) plates were purchased from Unitech at local companies. These plates were made up of silica gel on aluminium sheets. UV lamp (Vilber Lourmat VL) and its chamber were used for the identification of TLC spots after spraying with the proper reagents. Spectroscopic studies involved NMR and Mass Spectra (MS). The ${ }^{1} \mathrm{H}$ and ${ }^{13} \mathrm{C}$ NMR spectra were performed on a Bruker Avance III NMR operating at $500 \mathrm{MHZ}$. Mass spectrometric measurements were performed using Agilent Trap XCP Mass Spectrometer. All spectroscopic techniques were performed in the Kamal A. Shair Central Research Science Laboratory (KAS CRSL) at the American University of Beirut.

\section{Plants material}

The aerial parts of $I$. vis and I. vul species (Asteraceae) were collected in July 2013 from South Lebanon and Mount Lebanon while they were flowering. The two species were identified taxonomically by Prof. George Tohme, the previous president of the National Council for Scientific Research (CNRS) [2]. Dried voucher specimens were deposited at the Faculty Herbarium Museum (specimen no. 2015P030 I. vis and 2015-P031 I. vul). The aerial parts of the plants were cleaned to remove any residual soil, air-dried at room temperature in the shade, ground to a fine powder using a laboratory mill, stored in a dark place, and kept at room temperature $\left(22-23{ }^{\circ} \mathrm{C}\right)$ ready for extraction.

\section{Structure elucidation of some compounds using NMR, MS and UV $[15,16]$}

Different spectroscopic techniques were applied for characterization and further identification of isolated compounds. The ${ }^{1} \mathrm{H}$, the ${ }^{13} \mathrm{C}$, and the DEPT 135 NMR measurements were performed on a BRUKER Avance III HD NMR Spectrometer operating at 500 MHZ. Samples were dissolved in deuterated chloroform $\left(\mathrm{CDCl}_{3}\right)$ or Methanol $\left(\mathrm{CH}_{3} \mathrm{OD}\right)$ and the chemical shifts were reported in ppm values relative to the internal standard tetramethylsilane (TMS). Spectra were recorded and scanned using the residual non-deuterated solvent peaks as internal standards.
UV spectra were used to determine the type of sugar associated with the glycoside that has been isolated from the plant species. The sample was re-extracted from $\mathrm{KBr}$ pellets in order to determine the sugar using JASCO, V-570 UV/VIS/NIR spectrophotometer with VWTS-581 color analysis software.

\section{Cell lines}

Three different human cell lines have been used in this study; they included hepatocellular carcinoma (Hep-G2), human breast adenocarcinoma (MCF7) and colorectal adenocarcinoma (Caco2) cells. The cell lines were purchased from the American Type Culture Collection (ATCC), VA in the United States of America (USA). Cells were cultured in DMEM at $37{ }^{\circ} \mathrm{C}$ in a humidified $5 \% \mathrm{CO}_{2}$ incubator. Media were supplemented with $10 \%$ fetal bovine serum (FBS), 2 mmol L-glutamine, containing 100 units $/ \mathrm{ml}$ of penicillin $\mathrm{G}$ sodium, and 100 units $/ \mathrm{ml}$ of streptomycin sulfate (PEN-STREP). Monolayer cells were harvested by trypsin/EDTA treatment.

\section{Methods}

\section{Preparation of crude plant extracts}

I. vul: Aerial parts of $I . v u l(0.8 \mathrm{~kg})$ were dried, grinded, and extracted in the dark at room temperature with 1.5 liters of $80 \%$ ethanol, with occasional shaking for $48 \mathrm{~h}$. The extract was filtered then evaporated to dryness under vacuum at $40{ }^{\circ} \mathrm{C}$ using an automated Rotavapor yielding $45.2 \mathrm{~g}$ of residue. After that, $15 \mathrm{~g}$ of the extract was purified with petroleum ether $\left(40-60{ }^{\circ} \mathrm{C}\right)$. Then the remaining purified extract was partitioned in a 1-liter separatory funnel using EtAc. Another sample of the crude extract weighing $18.60 \mathrm{~g}$ was applied on a $100 \mathrm{~cm}$ height, $3 \mathrm{~cm}$ diameter silica gel wet packed column. Fractions were eluted using increasing polarity of PE: EtAc solvents. Collected fractions (total of 62) were dried, then applied on TLC plates, and resolved in 70:30 PE-EhAc and 80:20 DCM: MeOH mobile phase system consecutively. The TLC plates were visualized under $\mathrm{UV}$, and then sprayed with anisaldehyde reagent followed by heating in the oven at $105^{\circ} \mathrm{C}$ for $10 \mathrm{~min}$ (fig. 1).

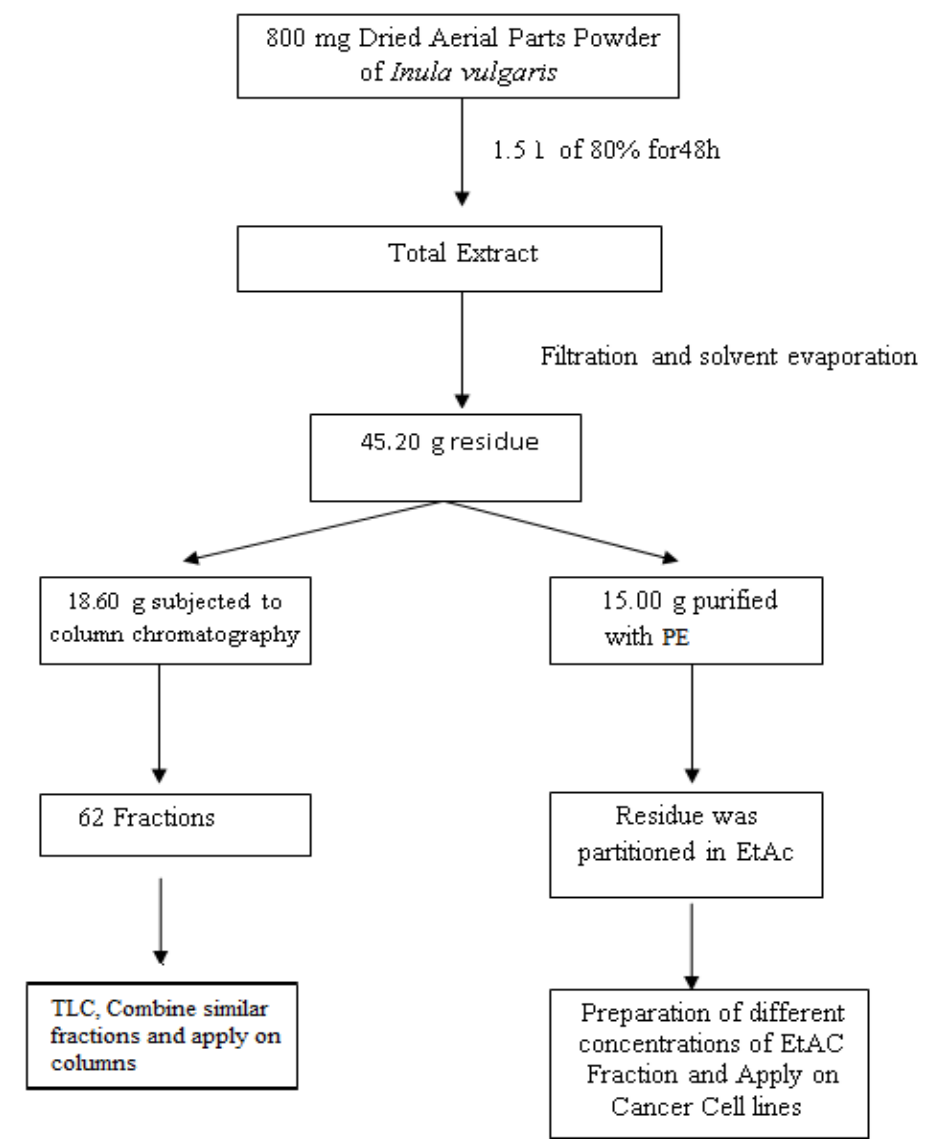

Fig. 1: Schematic representation of the $I$. vul extracts preparation and fractionation 
I. vis: Aerial parts of I. vis (5 kg) were dried, grinded, and extracted in the dark at room temperature with 4 litres of $80 \%$ ethanol, with occasional shaking for $48 \mathrm{~h}$. Similarly, the extract was filtered then evaporated to dryness at $40{ }^{\circ} \mathrm{C}$ yielding a residue of $160 \mathrm{~g}$. afterwards, $30 \mathrm{~g}$ of the extract was purified with PE $\left(40-60^{\circ} \mathrm{C}\right)$ and then partitioned in a 1-liter separatory funnel using EtAc.

\section{Treatment of cell lines}

The effect of $I$. vis and $I$. vul extracts on cell viability was examined. Three different cell lines were used in this study: hepatocellular carcinoma (HepG2), human breast adenocarcinoma (MCF7) and colorectal adenocarcinoma (Caco2) cells. Briefly, for the MTT test, the cells were inoculated into 96-well plates at plating densities of 10,000 cells/well, and four wells were used for each treatment. For Trypan blue test, the cells were inoculated into 24-well plates at plating densities of 500,000 cells/well, and three wells were used for each treatment. All the processes were carried out in a vertical laminar flow chamber previously washed with $70 \%$ ethanol [14]. The EtAc extracts of $I$. vis and $I$. vul were dissolved in dimethyl sulfoxide (DMSO, 99.9\%, HPLC grade), and then diluted 1000 -folds with the already prepared media. Four concentrations $(10 \mu \mathrm{g} / \mathrm{ml}, 30 \mu \mathrm{g} / \mathrm{ml}, 50 \mu \mathrm{g} / \mathrm{ml}$, and 70 $\mu \mathrm{g} / \mathrm{ml}$ ) of the extracts were added directly into the wells containing the cancer cells. Three independent experiments were performed and the data was presented as means \pm SD [17].

\section{Viability assays}

\section{Trypan blue exclusion assay}

The effect of extracts on the viability of cells was determined using trypan blue exclusion assay. Cells were seeded at a density of 500,000 cells/well using 24-well plates, treated with variable concentrations of extracts and then incubated in $\mathrm{CO}_{2} / \mathrm{O}_{2}$ for $24 \mathrm{~h}$ at $37{ }^{\circ} \mathrm{C}$. Cells were then trypsinized (harvested by trypsin/EDTA $0.25 \%$ in PBS). A $50 \mu \mathrm{l}$ sample of the cell suspension was taken and mixed with an equal volume of trypan blue, transferred to a hemocytometer, overlaid with a coverslip, and counted. Both clear live cells and blue dead cells were counted. The number of cells per $\mathrm{ml}$ was calculated and compared to the total number of cells. The percent viability was determined by using the formula [18]:

$\%$ Viability $=($ Live Cell Count $\backslash$ Total Cell Count $) \times 100$

\section{Cytotoxicity activity using MTT assay}

The effect of the different extracts was further investigated using the MTT assay according to the method of Alley et al.[19]. The assay briefly detects the reduction of MTT by mitochondrial dehydrogenase to a blue formazan product, which reflects the normal function of the mitochondria and cell viability. HepG2, MCF7, and Caco2 cells were seeded at 10,000 cells/well for cell lines in 96 well microplates. After $24 \mathrm{~h}$ of incubation at $37{ }^{\circ} \mathrm{C}$ in a $5 \% \mathrm{CO}_{2}$ incubator, the culture media were replaced by a medium containing the extracts $(100 \mu \mathrm{l})$ then incubated for $24 \mathrm{~h}$. The media were

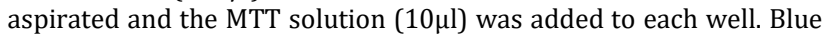
crystals were formed after $4 \mathrm{~h}$. The stop solution $(100 \mu \mathrm{l})$ was added and incubated further overnight. The reduced MTT was assayed at $550 \mathrm{~nm}$ using an ELISA microplate reader (Multiscan Co) [20, 21]. The percentage growth inhibition was calculated using the following formula:

$$
\% \text { Cell Viability }=\left[\left(A_{t}-A_{b}\right) \backslash\left(A_{c}-A_{b}\right)\right] \times 100
$$

$A_{t}=$ Absorbance value of test

$A_{b}=$ Absorbance value of blank

$\mathrm{A}_{\mathrm{c}}=$ Absorbance value of control

In the present study, due to the fact that we had colored extracts, blank wells were made for every extract concentration used without cells. The cells received the same amount of DMSO $(0.1 \%)$ and were used as a negative control. $\mathrm{IC}_{50}$ values were calculated to show the concentrations at which there was a 50\% inhibition of proliferation on any tested cell line. Stock solutions of the extracts were dissolved in DMSO then diluted with the medium and filtered using $0.2 \mu \mathrm{m}$ membrane filters. $\mathrm{IC}_{50}$ values were reported to indicate the average of the three replicates.

\section{Statistical analysis}

All values were presented as the means \pm SEM Statistical analysis was determined by using the "SPSS" (Statistical Package for the Social Sciences) computer program. A difference in the means with a pvalue $<0.05$ was regarded to be statistically significant.

\section{RESULTS AND DISCUSSION}

Comparative antiproliferative activity of $I$. vul versus $I$. vis using trypan blue viability test

The study evaluated the antiproliferative potential of different concentrations of extracts of two Lebanese plants. In order to compare the activities of the two plants on different cell lines and for the purpose of comparing the $\mathrm{IC}_{50} \mathrm{~s}$, different concentrations were used, and the plots of the percentage cell viability of cell lines against concentrations of extracts were carried. Fig. $2 \mathrm{a}, \mathrm{b}$, and $\mathrm{c}$ show the $\%$ viability curves of the cell lines after treatment with four different concentrations of EtAc fractions using the trypan blue dye exclusion technique.

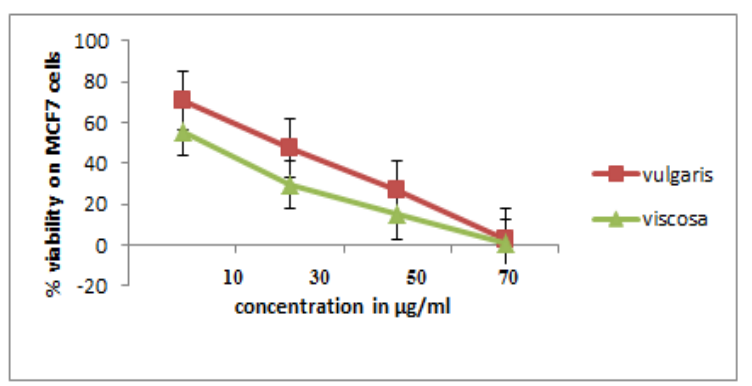

Fig. 2a: \% cell viability and characterization of MCF7 using trypan blue exclusion test on ethyl acetate fractions of two Inula species. Experiments were run in triplicates. Data are expressed in mean \pm SEM $P$-value $<0.05$ was considered statistically significant as compared to the control

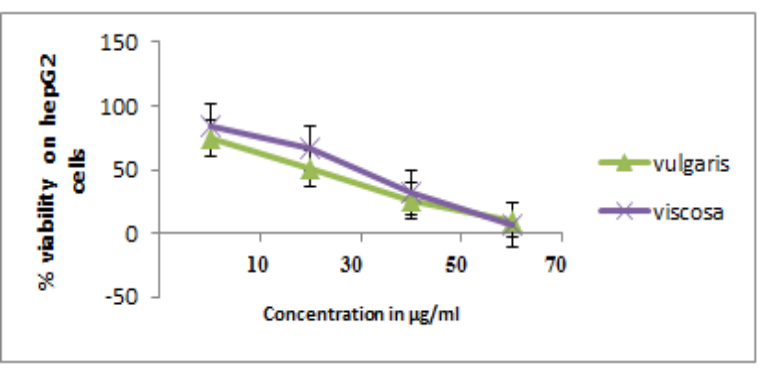

Fig. 2b: \% cell viability and characterization of HepG2 using trypan blue exclusion test on ethyl acetate fractions of two Inula species. Experiments were run in triplicates. Data are expressed in mean $\pm S E M P$-value $<0.05$ was considered statistically significant as compared to the control

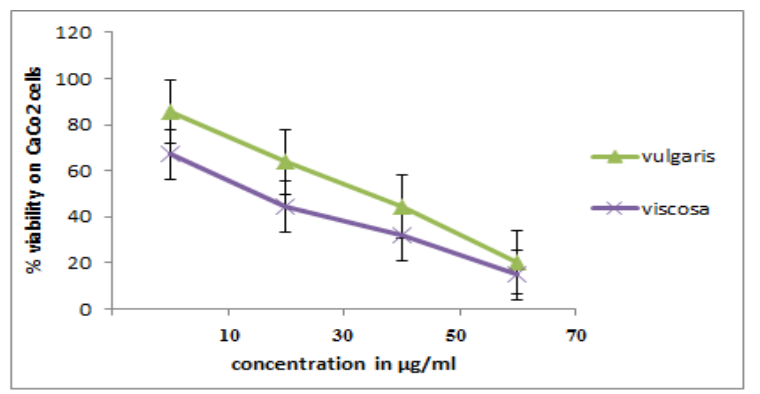

Fig. 2c: \% cell viability and characterization of $\mathrm{CacO} 2$ Using trypan blue exclusion test on ethyl acetate fractions of two Inula species. Experiments were run in triplicates. Data are expressed in mean \pm SEM $P$-value $<0.05$ was considered statistically significant as compared to the control 
Comparative antiproliferative activity of $I$. vul versus I. vis using MTT assay

MTT assay was used to determine the anti-proliferative effect of the ethyl acetate fractions on the three previously mentioned cell lines.

Fig. 3a, b, and c show the \% viability curves of the cell lines after treatment with four different concentrations of EtAc fractions using MTT.

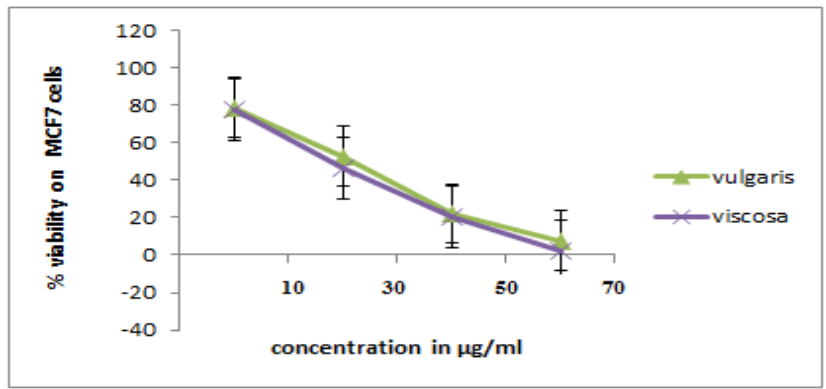

Fig. 3a: \% Cell viability and characterization of MCF7 Using MTT assay on ethyl acetate fractions of two Inula species.

Experiments were run in triplicates. Data are expressed in mean \pm SEM $P$-value $<0.05$ was considered statistically significant as compared to the control

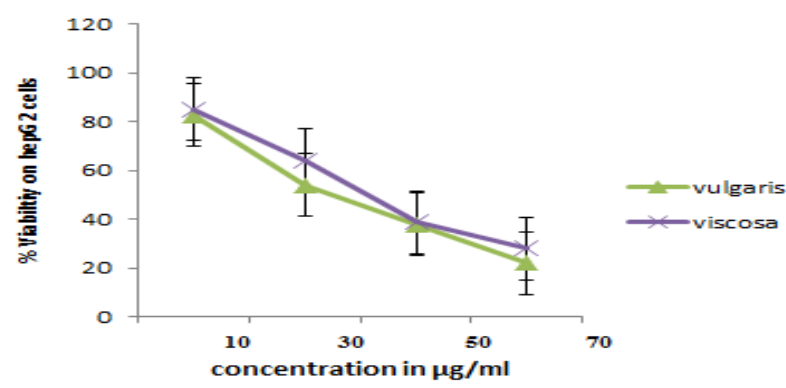

Fig. 3b: \% cell viability and characterization of hepG2 Using MTT assay on EtAC fractions of two Inula species. Experiments were run in triplicates. Data are expressed in mean \pm SEM $P$ value $<0.05$ was considered statistically significant as compared to the control

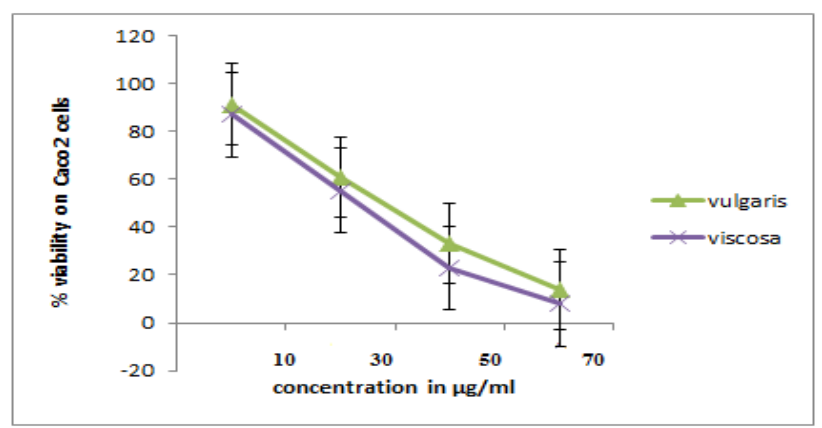

Fig. 3c: \% cell viability and characterization of Caco2 Using MTT assay on EtAC fractions of Two Inula species. Experiments were run in triplicates. Data are expressed in mean \pm SEM $P$ value $<0.05$ was considered statistically significant as compared to the control

The activities of the two plants on the three cell lines were compared using the $\mathrm{IC}_{50}$. In the cellular experiments, results were compared with DMSO treated cells. Our findings were consistent for the used tests: trypan blue and MTT assay. Our findings show that $I$. vul exerts a more potent effect on HepG2 while $I$. vis was more potent on MCF7. The IC 50 was graphically determined, whereby the values were $20 \mu \mathrm{g} / \mathrm{ml}$ and $27 \mu \mathrm{g} / \mathrm{ml}$ in the Trypan blue assay and MTT test respectively. For I. vis, the potency on MCF7 was shown in terms of $\mathrm{IC}_{50}$ at $9 \mu \mathrm{g} / \mathrm{ml}$ and $15 \mu \mathrm{g} / \mathrm{ml}$ in Trypan blue assay and MTT test respectively. On $\mathrm{CaCo} 2$, the $\mathrm{IC}_{50}$ of $I$. vis was $12 \mu \mathrm{g} / \mathrm{ml}$ in the Trypan blue assay and $22 \mu \mathrm{g} / \mathrm{ml}$ by the MTT test, indicating high potency. Since the $\mathrm{IC}_{50}$ of the extracts were less than $30 \mu \mathrm{g} / \mathrm{ml}$, this coincides with the American National Cancer Institute, which specified definite criteria for cytotoxic activity of plant extracts at $\mathrm{IC}_{50}$ less than $30 \mu \mathrm{g} / \mathrm{ml}$ [22]. Insignificant differences were observed among the two studied plants for each of the cells that were evaluated, which indicates comparable potencies.

Identification of three compounds isolated from EtAC fraction of $I . v u l$

Fractions 7, 8, 9 and 10 were collected together, and then the mixture was re-fractionated using DCM: $\mathrm{MeOH}$ system with an order of increasing polarity. Compounds I and II were eluted using 92:8 and 70:30 DCM: MeOH solvent systems respectively. Fractions 13 and 14 were added together then fractionated using petroleum ether: ethyl acetate. Compound III was isolated at 78\% of the solvent system. The compounds were kept to dry and crystallize from the eluting solvent.

\section{Compound I}

In order to elucidate the structure of compound I, different spectroscopic techniques were used. The obtained data were compared to published literature.

Compound I: ${ }^{1} \mathrm{H}$ NMR (CD $\left.\left.30 D\right)\right) \delta_{\mathrm{H}}: 2.828(\mathrm{~m}, \mathrm{H}-4), 2.969(\mathrm{~m}, \mathrm{H}-4)$ 5.024 (s, H-3), 5.518 (s,H-2), 5.954 (d, H-6, H-8), 6.684 (d, 8 Hz, H6) 6.795 (dd, J=1.5, 8 Hz, H-5 ), 6.923 (d, 1Hz, H-2`), 6.925 (s, H2 ",H-6"). Fig. 4a shows multi-signals that arise due to the splitting of hydrogen into close groupings of two or more resonances. This is a common feature in the spectra of compounds having different sets of hydrogen atoms bonded to adjacent carbon atoms. The signal splitting in proton spectra is usually small and is designated as J (referred to as the coupling constant).

According to the previous spectra, ${ }^{13} \mathrm{C}$ NMR (fig. $4 \mathrm{~b}$ ) analysis of compound I at $500 \mathrm{MHZ}$, using deuterated methanol $\left(\mathrm{CD}_{3} \mathrm{OD}\right)$ shows the following results:

${ }^{13} \mathrm{C}\left(\mathrm{CD}_{3} \mathrm{OD}\right) \delta_{\mathrm{C}}: 25.48(\mathrm{C}-4), 68.57(\mathrm{C}-3), 77.23(\mathrm{C}-2), 94.47(\mathrm{C}-8)$ 95.11(C-6), 97.97(C-10), 113.70(C-2`),114.59 (C5'), 117.97 (C-6'),

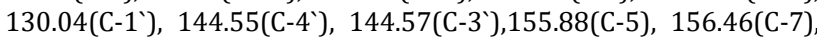
$156.46(\mathrm{C}-9)$. The values $(108.78,120.00,138.44,144.92$, and 166.21 ppm) were related to the gallic acid.

Fig. 4c represents the DEPT-135 spectrum used to differentiate the primary, secondary and tertiary carbon signals, but not the quaternary and carbonyl carbons. The appearance of 8 carbon signals (hydrogen containing carbons) at $\delta$ C value $117.97,114.59$ $113.69,108.78,95.11,94.46,77.23$, and $68.57 \mathrm{ppm}$ is interpreted as primary, secondary and tertiary carbons.

Based on the previous data, the ${ }^{1} \mathrm{H}$ NMR spectrum has shown 1,3,4substituted aromatic protons at 6.923, 6.795 and 6.684. These protons were related to $\mathrm{H}-22^{`}, \mathrm{H}-5^{\prime}$, and $\mathrm{H}-6^{`}$ respectively. Signals of wo meta coupling protons were shown at $\delta \mathrm{H} 5.954$ and were related to $\mathrm{H}-6$ and $\mathrm{H}-8$. A methylene group was also identified at $\delta \mathrm{H} 2.828$ and 2.969 for H-4. Finally, two methine protons were identified at: 5.024 and 5.518 for $\mathrm{H}-3$ and $\mathrm{H}-2$ respectively. The ${ }^{13} \mathrm{C}$ NMR detected 15 carbon signals including twelve aromatic carbons, one oxygenated aliphatic carbon and two aliphatic carbons. In fact, the aromatic CH signals were observed at 117.97, 114.59, 113.69, 95.11, and $94.46 \mathrm{ppm}$. The ${ }^{1} \mathrm{H}$ and ${ }^{13} \mathrm{C}$ NMR spectra were similar to catechin except for the presence of a gallic acid moiety at $\delta \mathrm{H} 6.925\left(\mathrm{~s}, \mathrm{H}-2^{\prime \prime}, \mathrm{H}-\right.$ $\left.6^{\prime \prime}\right)$ and $\delta \mathrm{C}$ (108.78 (C-2“,C-6“), 120.00 (C-1“), 138.44 (C-4”), $144.92\left(\mathrm{C}-3\right.$ ", $\left.5^{\prime \prime}\right)$, and 166.21 (-COO) ppm)

By direct comparison of the ${ }^{1} \mathrm{H},{ }^{13} \mathrm{C}$, DEPT-135 NMR spectral data with those of an authentic reference, compound I was identified as epicatechin-30-gallate [23]. 


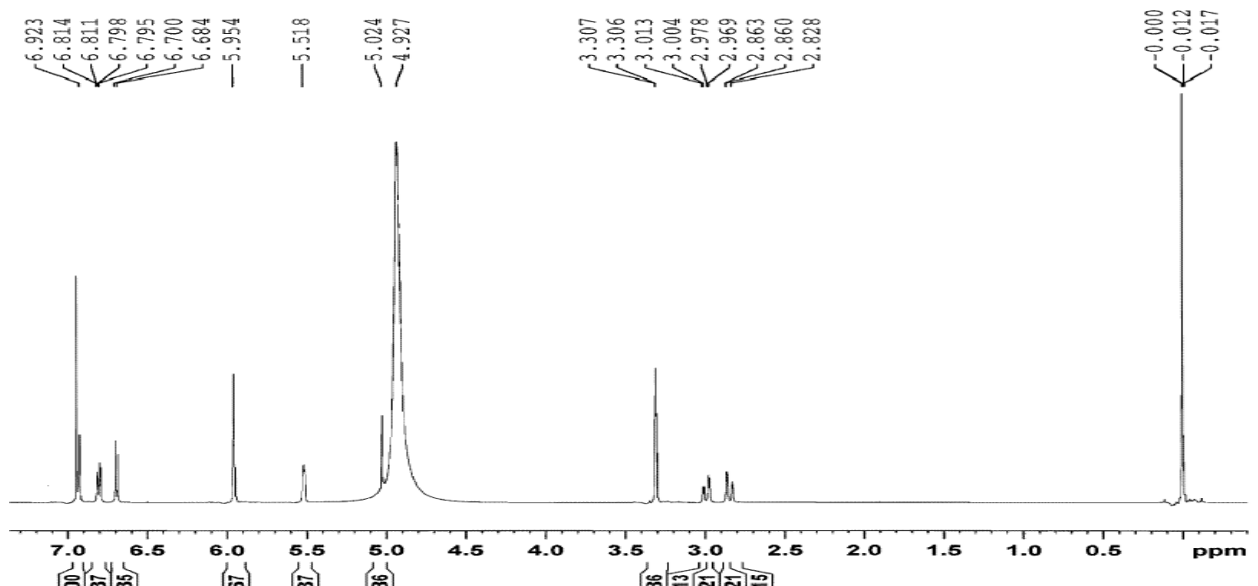

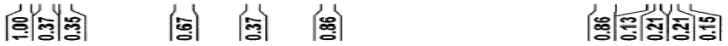

Fig. 4a: Characterization of compound I isolated from $I$. vul using ${ }^{1} \mathrm{H}$ NMR

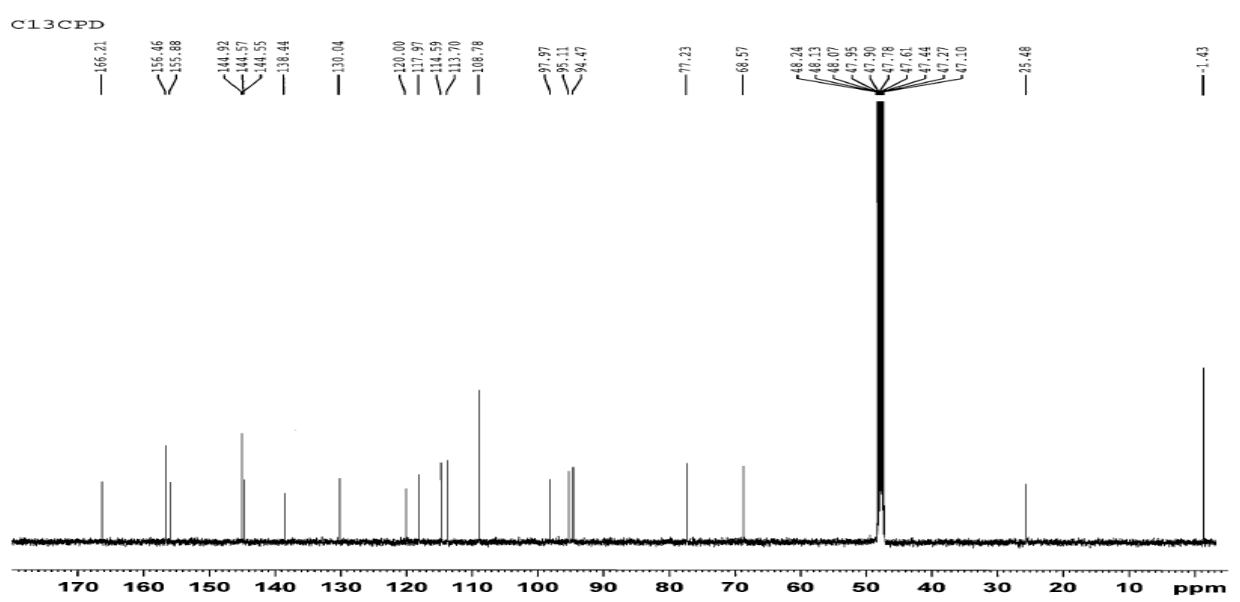

Fig. 4b: Characterization of compound I isolated from I. vul using ${ }^{13} \mathrm{C} \mathrm{NMR}$

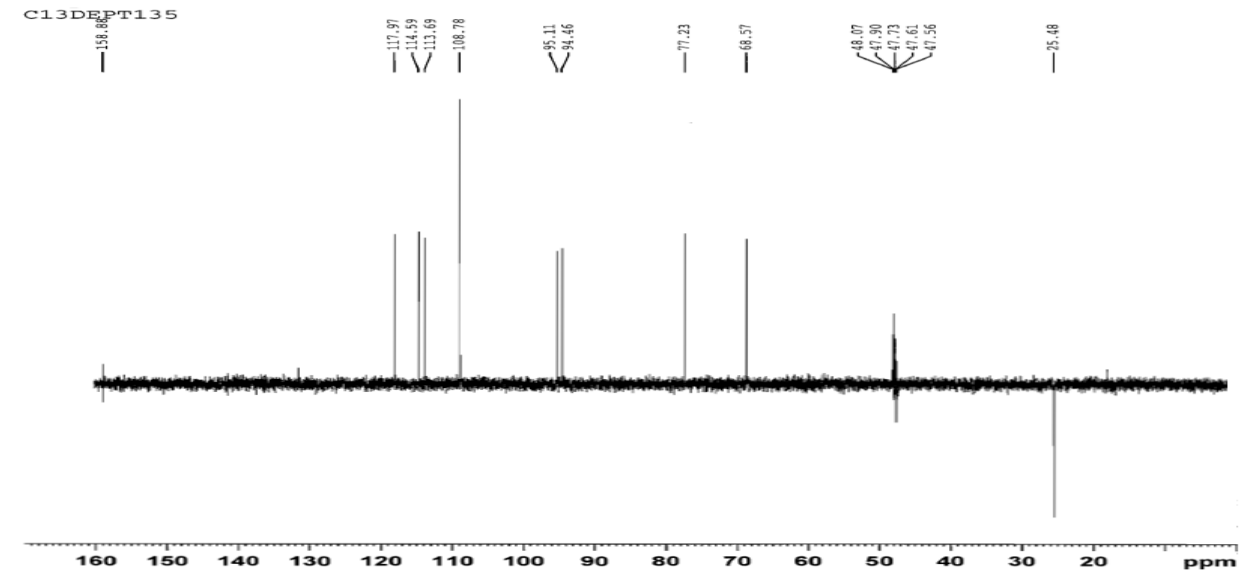

Fig. 4c: Characterization of compound I isolated from I. vulgaris using DEPT-135

\section{Compound II}

Fig. 5a represents ${ }^{1} \mathrm{HNMR}$ spectra of compound II.

${ }^{1} \mathrm{H}$ NMR (CD $\left.\left.{ }_{3} \mathrm{OD}\right)\right) \delta_{\mathrm{H}}: 6.176(\mathrm{~d}, 2.0 \mathrm{~Hz}, \mathrm{H}-6), 6.383$ (d, $\left.2.0 \mathrm{~Hz}, \mathrm{H}-8\right), 6.874$ (d, $4.0 \mathrm{~Hz} \mathrm{H}-5$ ) ) 7.618 (dd,J=2.5, 8.5 Hz,H-6 ), 7.730 (d, $2.1 \mathrm{~Hz}, \mathrm{H}-2^{\prime}$ ).

Fig. 5b shows ${ }^{13} \mathrm{C}$ NMR analysis of compound II, using deuterated methanol (MeOD): ${ }^{13} \mathrm{C}\left(\mathrm{CD}_{3} \mathrm{OD}\right) \delta_{\mathrm{c}:} 93.01(\mathrm{C}-8), 97.83(\mathrm{C}-6), 103.10(\mathrm{C}-$ 10), 114.58(C-2',C),114.82 (C5'), $120.27\left(\mathrm{C}^{\prime} 6^{\prime}\right), 122.72\left(\mathrm{C}-1^{\prime}\right), 135.83$
(C-3), 144.81(C-3`), 146.58(C-2),147.36(C-4'), $156.79(\mathrm{C}-9), 161.79$ (C-5), 164.16 (C-7), 175.92 (C-4).

The appearance of 5 carbon signals in fig. $5 \mathrm{c}$ at $\delta \mathrm{C}$ value 120.27 , $114.82,114.57,97.83$, and $93.01 \mathrm{ppm}$ is interpreted as primary, secondary and tertiary carbons. In fact, the signals observed at 120.27, 114.82, 114.57, 97.83, and $93.01 \mathrm{ppm}$ were related to aromatic $\mathrm{CH}$. The previous spectra have revealed a lot of aromatic protons. The two doublet peaks at 6.176 and 6.383 ppm were 
related to two aromatic protons at $\mathrm{C}_{6}$ and $\mathrm{C}_{8}$. The signals at (7.73 $\mathrm{ppm})$ and $(7.61 \mathrm{ppm})$ were related to $\mathrm{C}_{2}$ and $\mathrm{C}_{6}$ 'of the catechol ring. By direct comparison of the ${ }^{1} \mathrm{H},{ }^{13} \mathrm{C}$, DEPT-135 NMR spectral data with those of an authentic sample, compound II was identified with a formula of $\mathrm{C}_{15} \mathrm{H}_{10} \mathrm{O}_{7} ;$; 2-(3,4-Dihydroxyphenyl)-3, 5, 7-trihydroxy$4 \mathrm{H}-1$-benzopyran-4-one, which is the flavonoid quercetin [24].

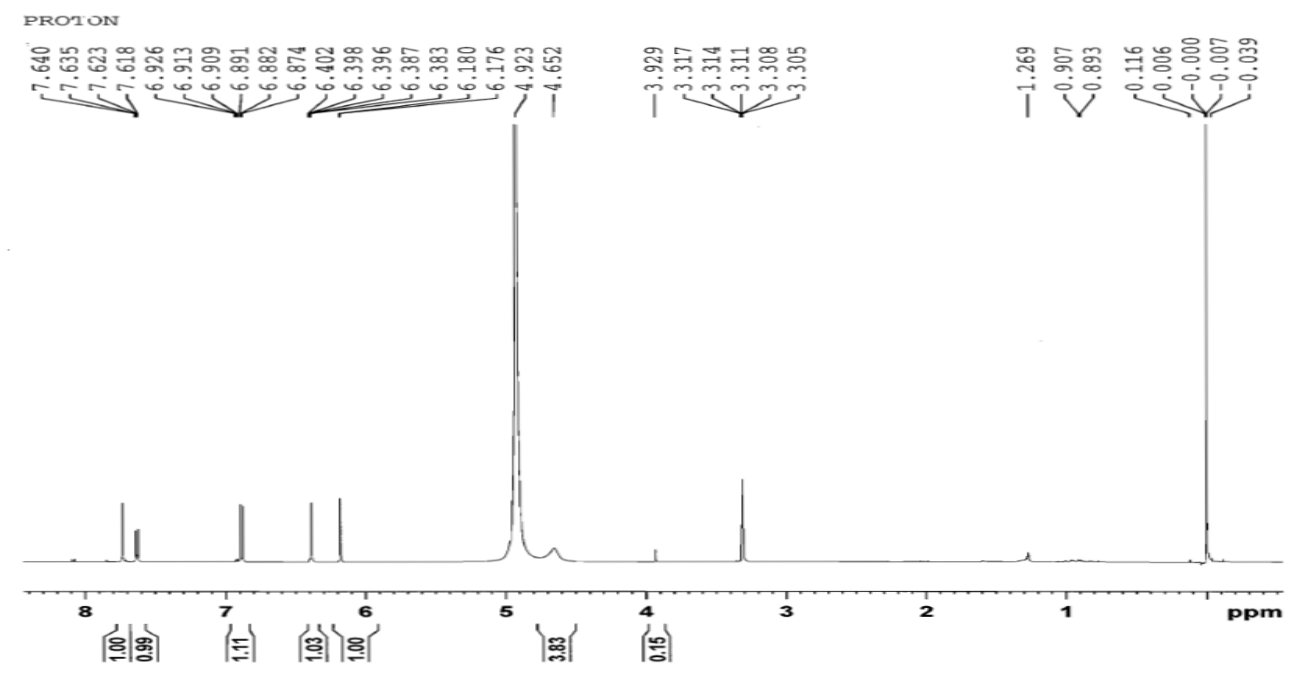

Fig. 5a: Characterization of compound II isolated from I. vul using ${ }^{1} \mathrm{H}$ NMR

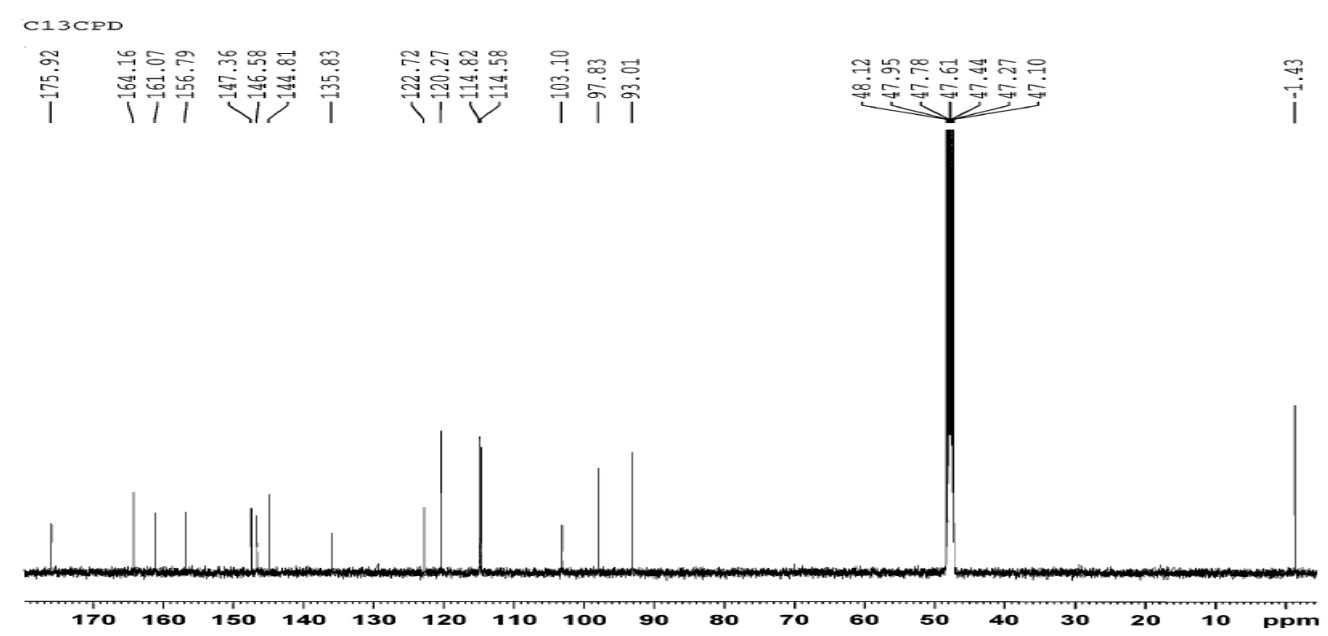

Fig. 5b: Characterization of compound II isolated from I. vulgaris using ${ }^{13} \mathrm{C}$ NMR

C13DEPT135
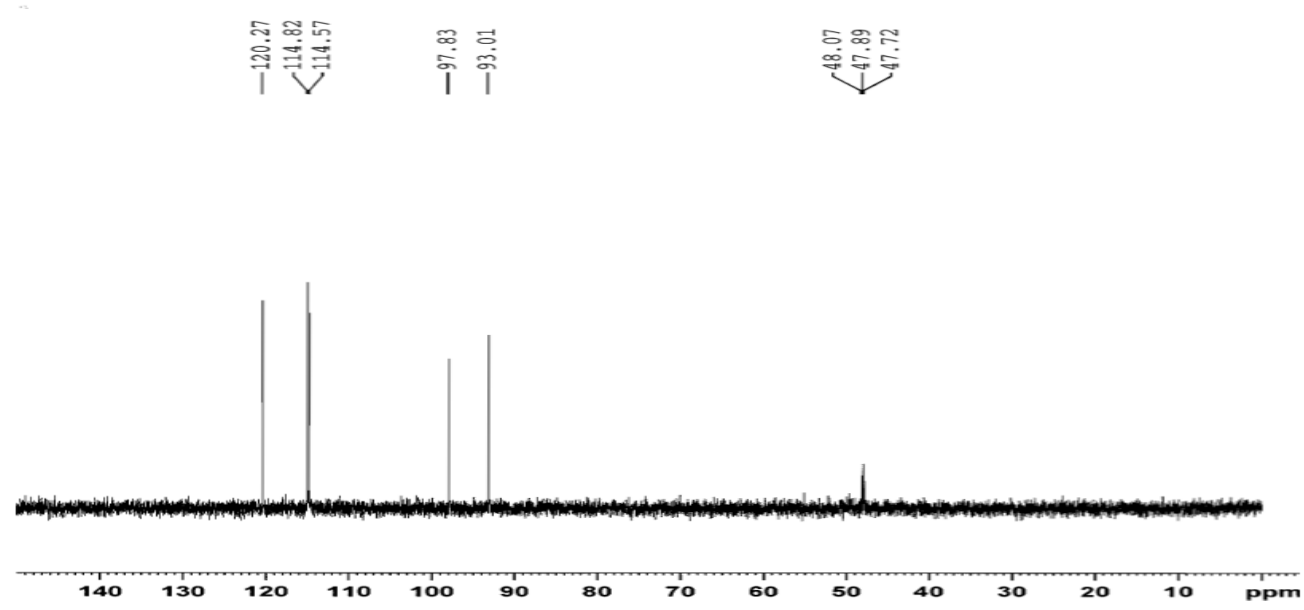

Fig. 5c: Characterization of compound II isolated from $I$. vul using ${ }^{13} \mathrm{C}$ DEPT135 


\section{Compound III}

The ${ }^{1} \mathrm{H}$ NMR and ${ }^{13} \mathrm{C}$ spectroscopy of compound III were determined using deuterated methanol and represented in fig. $6 \mathrm{a}$ and fig. $6 \mathrm{~b}$ respectively.

Compound III: ${ }^{1} \mathrm{H}$ NMR $\left.\left(\mathrm{CD}_{3} \mathrm{OD}\right)\right) \delta_{\mathrm{H}} 0.901$ (s, H-6 $\left.{ }^{\prime \prime}\right), 1.112\left(\mathrm{~m}, \mathrm{H}-6{ }^{\prime \prime}\right)$, 1.298 (s, H-6"'), 3.150 (s, H-4 ")), 3.265 (m, H-2"), 3.2281 (d,3 Hz, H3"), 3.303 (s,H-4"), 3.306 (m, H-5"), 3.345 (m, H-6"), 3.426 (m, H-5"'), 3.469 (d, 1Hz, H-3"'). 3.629 (s,H-2"'), 3.810 (d,2.5 Hz, Hb-6"), 4.517 (d, $\left.8.5 \mathrm{~Hz}, \mathrm{H}-1^{\prime \prime}\right), 5.110$ (d, 5Hz, H-1"), 6.203 (d, 2.0Hz, H-6), 6.394(d, $2.0 \mathrm{~Hz}, \mathrm{H}-8$ ), 6.859 (d, $5.0 \mathrm{~Hz} \mathrm{H}-5^{\prime}$ ), 7.663 (m,H-6'), 7.701 (s, H-2').

${ }^{13} \mathrm{C}\left(\mathrm{CD}_{3} \mathrm{OD}\right) \delta_{\mathrm{c}:} 17.91$ (C-6")), 68.56 (C-6”),69.74 (C-5“"), 71.40 (C4"),72.12 (C2“"),72.23 (C-3"'),73.94 (C-4"'),75.73 (C-2"),77.23 (C3"),78.19 (C-5"),94.97 (C-8),99.80 (C-6),100.12 (C-1'”),,102.45 (C$1^{\prime \prime)}, 104.76$ (C-10), 116.08 (C-2'),117.67 (C5'), 123.11(C-6), 123.56 (C-1 $), \quad 135.61$ (C-3), $145.89\left(\mathrm{C}-3^{\circ}\right), \quad 149.89\left(\mathrm{C}^{\prime} 4^{\prime}\right), 158.58(\mathrm{C}-2)$, 159.50(C-9), $163.50(\mathrm{C}-5), 166.50$ (C-7), 180.34 (C-4).

The DEPT-135 spectrum (fig. 6c) has revealed the appearance of 17 hydrogen containing carbon signals. These carbons appear at $\delta \mathrm{C}$ value $16.49,67.13,68.31,69.97,70.69,70.80,72.51,74.31,75.80$ $76.76,93.54,98.68,101.02,103.33,114.65,116.24$, and $122.13 \mathrm{ppm}$. Mass spectral studies have revealed two sharp peaks with $\mathrm{m} / \mathrm{z}$ value of 637.5 and 611.1. These results were compared to previous literature. Based on the spectral data, the compound is a glycoside that is formed up of two sugars. The two types of sugars could be identified using UV spectra analysis. The UV spectrum of compound
III has shown two major absorption bands at $405 \mathrm{~nm}$ and $257 \mathrm{~nm}$, which indicated the presence of flavonol structure. Five aromatic protons signals appeared in the ${ }^{1} \mathrm{H}$ NMR, which support the assigned chemical structure of the isolated compound as previously deduced from UV spectral analysis. The ${ }^{1} \mathrm{H}$ NMR spectrum also supported the presence of rhamnose proton $\mathrm{H}-1$ signal at $\delta \mathrm{H} 4.51 \mathrm{ppm}$ and glucose $\mathrm{H}-1$ signal at $\delta \mathrm{H} 5.11 \mathrm{ppm}$. The protons of the methyl group of rhamnose have appeared as three signals at $0.901(\mathrm{~s}), 1.112(\mathrm{~m})$ 1.298 (s). The remaining protons of the sugar moiety were resonated between 3.15 and $3.81 \mathrm{ppm}$. The ${ }^{13} \mathrm{C}$ NMR spectrum showed 27 carbon signals, 15 carbons of which were signals of the flavonol skeleton. The DEPT signals were interpreted as primary, secondary and tertiary carbons. In fact, the aromatic $\mathrm{CH}$ signals were observed at 122, 116.24, 114.65, 98.68, and 93.54 ppm. Compound III gave yellow colour with concentrated ammonia, which indicates its nature being either a flavonoid or a flavonoid glycoside. The FTIR analysis of the compound III gave a broad band peak at $3386.24 \mathrm{~cm}$. 1, 3600 to $3000 \mathrm{~cm}^{-1}$ which may be due to $\mathrm{OH}$ stretching. Bands at $2968,2926,2865,2740, \mathrm{~cm}^{-1}$ can be attributed to $\mathrm{H}-\mathrm{C}-\mathrm{H}$ asymmetrical stretching. While bands at $1654.78,1604.03$ and 1560 $\mathrm{cm}^{-1}$ may be due to $\mathrm{C}=0$ stretching. The bands at 1520,1480 , $1450.39,1359.41,1301.12,1270,1250 \mathrm{~cm}^{-1}$ may indicate-C-Cstretching. The bands at 1202.49 and $1160 \mathrm{~cm}^{-1}$ could be related to$\mathrm{C}$-C-stretching, while bands at 1062, 920, $610 \mathrm{~cm}^{-1}$ may represent$\mathrm{C}=\mathrm{C}$-mono substituents. By direct comparison of the ${ }^{1} \mathrm{H},{ }^{13} \mathrm{C}$, DEPT135 NMR, FTIR, MS, and UV spectral data with those of an authentic sample, compound III was identified as quercetin 3-0-rutinoside or Rutin [25].

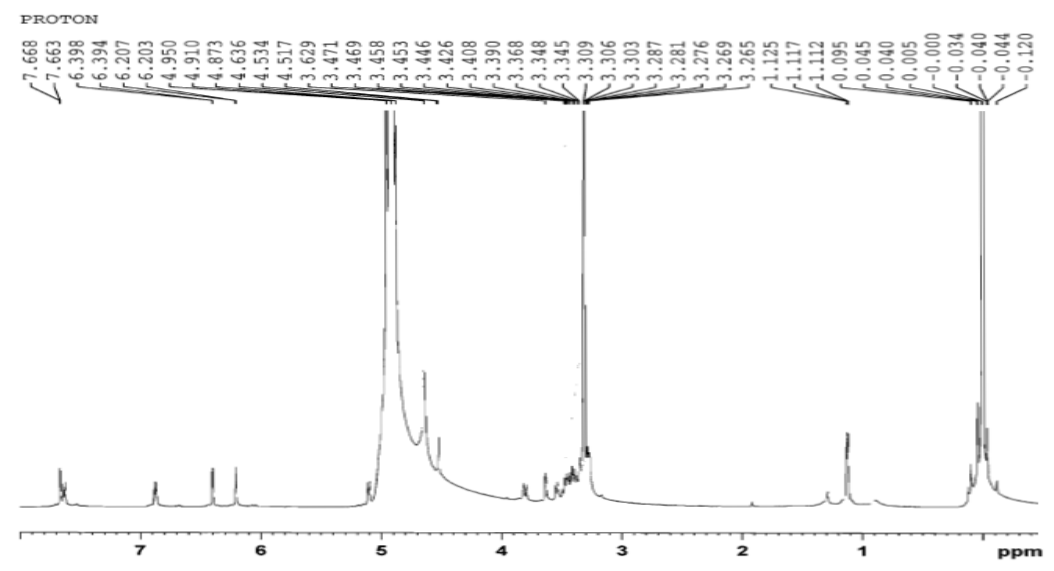

Fig. 6a: Characterization of compound III isolated from $I$. vul using ${ }^{1} \mathrm{H}$ NMR

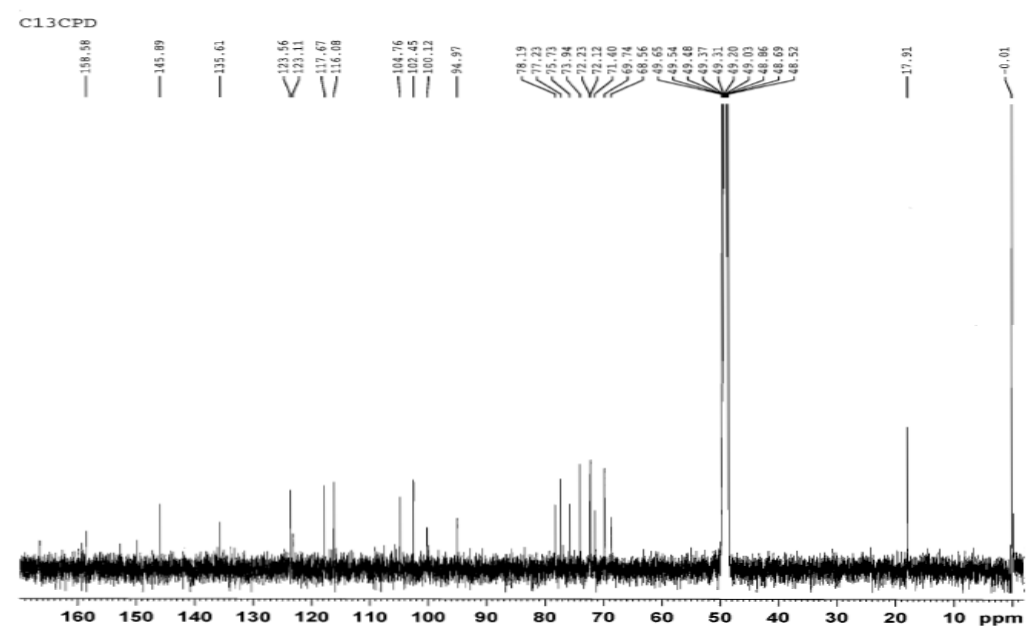

Fig. 6b: Characterization of compound III isolated from I. vul using ${ }^{13} \mathrm{C}$ NMR 


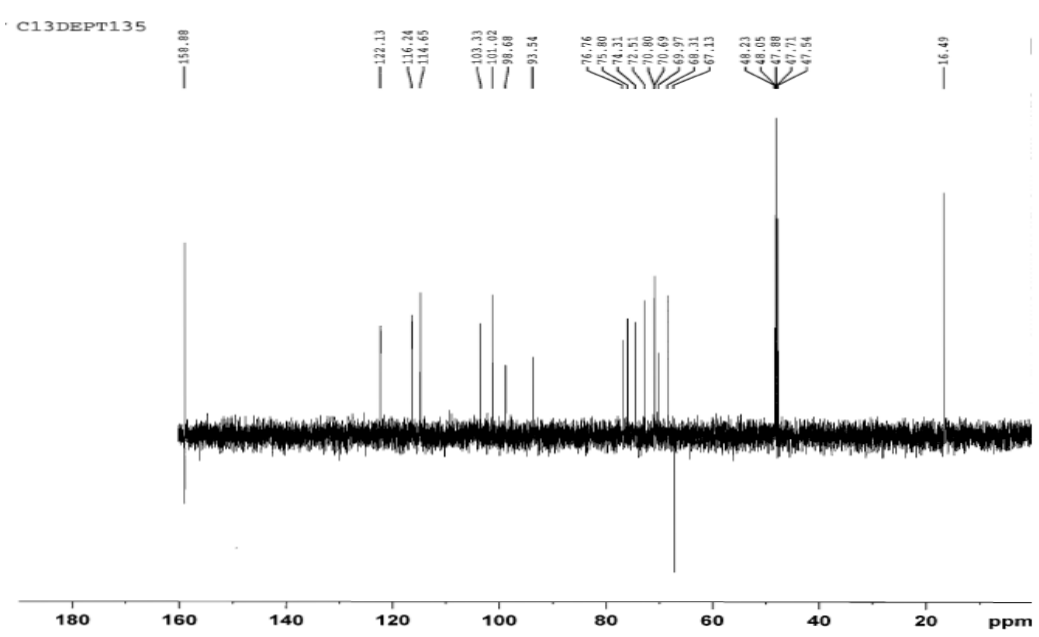

Fig. 6c: Characterization of compound III isolated from I. vulgaris using ${ }^{13} \mathrm{C}$ DEPT135

The obtained anti-cancer results are not an exception where many anti-cancer studies done on plant species have shown anticancer effects. It is widely accepted that the antiproliferative activity could be related to the active principles of the various fractions, especially flavonoids, flavonoid glycosides, and sesquiterpenes, which are major components of $I$. species [26.27]. The association between flavonoids from one side and cancer types from another has been reported. The role of dietary flavonoids in cancer prevention indicates that flavonoids have important effects on cancer chemoprevention and chemotherapy. Many mechanisms of action have been identified, including carcinogen inactivation, antiproliferation, cell cycle arrest, induction of apoptosis, differentiation and inhibition of angiogenesis [28]. In this field, it seems that the antiproliferative activity of $I$. vul extracts is mainly due to its flavonoidal content, including the 3 isolated compounds. It was found that epicatechin gallate and catechin gallate have great anti-proliferative effects. In addition, they have superior effects as compared to the well-known anti-proliferative "epigallocatechin gallate" in growth suppression in pancreatic tumor cells[29]. Such studies provide evidence that catechins show an antiproliferative potential that could possibly increase the efficacy of classical anticancer therapies. Similarly, for quercetin and rutin, many studies have suggested the potential effects of those two substances in cancer therapy. Numerous in vitro and in vivo experiments have shown various mechanisms of action that could suppress multiple oncogenic signalling pathways [30]. These compounds were previously isolated from $I$. vis and have shown great antiproliferative effects, which emphasizes their involvement in the anticancer effects of $I$. vul. Updating the database related to these dietary flavonoids will deliver significant information for future epidemiological studies. The importance of this part of our study is the investigation of the anticancer effects of these Lebanese plant species that have never been previously studied. Furthermore, studies done on $I$. vul species are considered as novel ones; this is the first pharmacological study on this species in the whole world.

\section{CONCLUSION}

This is the first study to be performed on the plant species $I$. vul. Our research has shown that this herb has anti-cancer effects which were concentrated in its aerial parts and were effective against the three aforementioned cell lines. Two glycosides and one flavonoid were isolated and identified, however, such species needs further investigation, to isolate more active compounds. This study complements the worldwide ethnomedicine activities that are still ongoing to develop new and improved pharmaceutical agents to treat many diseases.

\section{ACKNOWLEDGMENT}

Great thanks to the supervisors and lab technicians at both the American University of Beirut and Beirut Arab University, especially to Ms. Rania Chatila who has run various spectroscopic techniques applied on the identified compounds.

\section{ABBREVIATION}

Inula viscosa (I. vis), Inula vulgaris (I. vul), Nuclear Magnetic Resonance spectrometry (NMR), Microgram per milliliter $(\mu \mathrm{g} / \mathrm{ml})$, Petroleum ether (PE), dichloromethane (DCM), ethyl acetate (EtAc), methanol $(\mathrm{MeOH})$, streptomycin sulfates (PEN-STREP), Mass spectroscopy (MS), Ultra violet spectroscopy (UV), Fourier transfer infrared spectroscopy (FTIR), Dulbecco's modified Eagle's medium (DMEM), 10\% fetal bovine serum (FBS).

\section{AUTHORS CONTRIBUTION}

I have participated sufficiently in the conception and design of this work and the analysis of the data, as well as the writing of the manuscript, to take public responsibility for it. Dr. Julnar Usta has supervised all the antiproliferative studies, the follow-up, and finalisation of the manuscript. Dr. Youssef Mounimne has supervised the different spectroscopic techniques involved in the analysis and identification of compounds. Prof. Maha Aboul-Ela has selected the point of research and followed the phytochemical section of the study, in addition to the revision of the manuscript together with Prof. Abdalla El-Lakany. Neither has the manuscript nor one with substantially similar content under my authorship been published nor is being considered for publication elsewhere.

\section{CONFLICT OF INTERESTS}

All authors have nothing to declare

\section{REFERENCES}

1. Seca AM, Grigore A, Pinto DC, Silva AM. The genus Inula and their metabolites: from ethnopharmacological to medicinal uses. J Ethnopharmacol 2014;154:286-310.

2. Tohme G, Tohme H. Illustrated Flora of Lebanon. Lebanese National Council for Scientific Research; 2007.

3. Manez S, Hernandez V, Giner RM, Rios JL, Recio M. Inhibition of pro-inflammatory enzymes by Inu-Visco Lide, a sesquiterpene lactone from I. vis. Fitoterapia 2007;78:329-31.

4. Dom DC, Alexenizer MH, Engstler JG, Dom A. Tumor cell specific toxicity of I. helenium extracts. Phytother Res 2006;20:970-80.

5. Assi M, Aboul-Ela M, El-Lakany A. A comparative phytochemical and antimicrobial study of some Inula species Growing in Lebanon", MS thesis, BAU; 2011.

6. Nesterova IuV, Zelenskaia KL, Vetoshkina TV, Aksinenko SG, Gorbacheva AV, Gorbatykh NA. Mechanisms of antistressor activity of Inula helenium preparations. Eksp Klin Farmakol 2003;66:63-5.

7. Zhang H, Wen J, Wang Y, Zheng B, Han M. Flavonoids from Inula britannica inhibit injury-induced neointimal formation by 
suppressing oxidative-stress generation. J Ethnopharmacol 2009;126:176-83.

8. Aboul-Ela M, El lakany A, Abdel-Kader M, Alqasoumi S, Shamseddine S, Hammoda HM. New quinic acid derivatives from hepatoprotective I. crithmoides root extract. Helv Chim Acta 2012;95:61-6.

9. Zelenskaja KL, Povetjeva TN, Pashinskij VG. Anesthetic effect of alcohol extractions from Inula helenium. Rastit Resur 2003;39:82-6.

10. Torre LA, Rebecca LFB, Jacques S, Joannie F, Tieulent L, Jemal A. Global cancer statistics. CA Cancer J Clin 2015;65:87-108.

11. Shamseddine A. Cancer trends in Lebanon: a review of incidence rates for the period of 2003-2008 and projections until 2018. Population Health Metrics 2014;12:4.

12. Hartwell JL. Plants used against cancer: a survey. Lawrence MA. Quarterman Publications; 1982;438-9.

13. Cordell G. Natural products in drug discovery-creating a new vision. Phytochem Rev 2002;1:261-73.

14. Paul M, Brüning G, Bergmann J, Jauch J. A thin-layer chromatography method for the identification of three different olibanum resins (Boswellia serrata, Boswellia papyrifera and Boswellia carterii, respectively, Boswellia sacra) Phytochem Anal 2012;23:184-9.

15. Rodrigueg J, Yanez J, Vicente V, Alcaraz M, Benavente-García O, Lazona JA, et al. Effects of several flavonoids on the growth of B16f10 and SK-MEL-1 melanoma cell lines: the relationship between structure and activity. Melanoma Res 2002;12:99-107.

16. Uzair M. Phytochemical and biological studies of $C$. bonarenesis, Euphorbia prostata and Euphorebia helioscopia" PhD thesis, Bahauddin Zakariya University, Pakistan; 2009.

17. Mahmouda A, Al-Shihrya SS, Hegazy MF. The biological activity of a phloroglucinol glucoside derivative from Conyza aegyptiaca. Natl Res Centre 2009;64:513-7.

18. Sanjay P, Nirav G, Ashok S, Anand S. In vitro cytotoxicity activity of Solanum Nigrum extract against HELA cell line and VERO cell line. Int J Pharm Pharm Sci 2009;1:38-45.

19. Alley MC, Scudiero DA, Monks A, Hursey ML, Czerwinski MJ, Fine DL, et al. Feasibility of drug screening with panels of human tumor cell lines using a microculture tetrazolium assay. Cancer Res 1988;48:589-601.
20. Lau C, Ho C, Kim C, Leung K, Fung K, Tse T, et al. Cytotoxic activities of Coriolus versicolor (Yunzhi) extract on human leukemia and lymphoma cells by induction of apoptosis. Life Sci 2004;75:797-808

21. Mosmann T. Rapid colorimetric assay for cellular growth and survival: application to proliferation and cytotoxicity assays. J Immunol Methods 1983;65:55-63.

22. Saikali M, Ghantous A, Halawi R, Talhouk SN, Saliba N, Darwiche N Sesquiterpene lactones isolated from indigenous middle eastern plants inhibit tumor promotor-induced transformation of JB6 cells. BMC Complementary Altern Med 2012;12:89.

23. Cai Y, Davies AP, Lewis JR. ${ }^{1} \mathrm{H}$ and ${ }^{13} \mathrm{C}$ NMR assignments of some green tea polyphenols. Magn Reson Chem 1996;34:887-90.

24. Itharat A, Houghton PJ, Eno-Amooquaye E, Burke PJ, Sampson JH Raman A. In vitro cytotoxic activity of Thai medicinal plants used traditionally to treat cancer. J Ethnopharmacol 2004;90:33-8.

25. MoffoK S, Haba H, Lavaud C, Long C, Benkhaled M. Chemical constituents of Centaurea omphalotricha. Rec Nat Prod 2012;6:292-5.

26. El-Lakany A, Aboul-Ela M, Hammouda HM, Ghazi NM Mahmoud Z. New Methoxylated flavonols from I. crithmoides L. Die Pharmazie 1996;51:435-6.

27. El-Lakany A, Aboul-Ela M, Hammouda HM, Abdul-Ghani M. Three new butyl glycosides from I. crithmoides L. growing in Egypt. Die Phrmazie 2003;58:940-2.

28. Ren W. Flavonoids: promising anticancer agents. Med Res Rev 2003;23:519-34.

29. Messaoudi M. Cytotoxic effect and chemical composition of $I$. vis from three different regions of morocco. Eur J Med Plants 2016;16:1-9.

30. Claudia KR. Epicatechin gallate and catechin gallate are superior to epigallocatechin gallate in growth suppression and anti-inflammatory activities in pancreatic tumor cells. Cancer Sci 2011;102:728-34.

\section{How to cite this article}

- Assi M, Usta J, Mounimne Y, Aboul-Ela M, El Lakany A Phytochemical study and the antiproliferative activity of Inula vulgaris species grown in lebanon. Int J Pharm Pharm Sci 2017;9(8):75-83. 